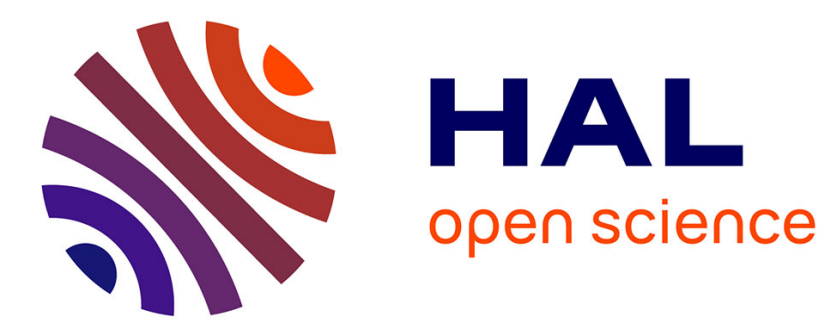

\title{
Competition, financial intermediation and riskiness of banks: Evidence from the Asia-Pacific region
}

Wahyoe Soedarmono, Amine Tarazi

\section{To cite this version:}

Wahyoe Soedarmono, Amine Tarazi. Competition, financial intermediation and riskiness of banks: Evidence from the Asia-Pacific region. 2015. hal-01114380

\section{HAL Id: hal-01114380 \\ https://hal-unilim.archives-ouvertes.fr/hal-01114380}

Preprint submitted on 9 Feb 2015

HAL is a multi-disciplinary open access archive for the deposit and dissemination of scientific research documents, whether they are published or not. The documents may come from teaching and research institutions in France or abroad, or from public or private research centers.
L'archive ouverte pluridisciplinaire HAL, est destinée au dépôt et à la diffusion de documents scientifiques de niveau recherche, publiés ou non, émanant des établissements d'enseignement et de recherche français ou étrangers, des laboratoires publics ou privés. 


\title{
Competition, financial intermediation and riskiness of banks: Evidence from the Asia-Pacific region
}

\author{
Wahyoe Soedarmono ${ }^{1}$ \\ Sampoerna University, Faculty of Business / Sampoerna School of Business \\ Mulia Business Park Building D, Jl. MT. Haryono Kav. 58-60, \\ Jakarta 12780, Indonesia \\ Amine Tarazi \\ Université de Limoges, LAPE, 5 rue Félix Eboué BP3127, 87000 Limoges, France
}

\begin{abstract}
From a sample of commercial banks in the Asia-Pacific region over the 1994-2009 period, this study highlights that banks in less competitive markets exhibit lower loan growth and higher instability. Such instability is further followed by a decline in deposit growth, suggesting that Asian banks are also subject to indirect market discipline mechanisms through bank competition. This study therefore sheds light on the importance of enhancing bank competition to overcome bank risk and strengthen financial intermediation. Likewise, this study advocates the importance of strengthening market discipline to reduce bank riskiness regardless of the degree of competition in the banking industry.
\end{abstract}

Keywords: Bank competition, loan growth, risk, market discipline, Asia Pacific JEL Classification: G21, G28

\footnotetext{
${ }^{1}$ Corresponding author. Tel.: +62 217942340 .

Email: wahyoe.soedarmono@usbi.ac.id (W. Soedarmono), amine.tarazi@unilim.fr (A. Tarazi)
} 


\section{Introduction}

In the wake of the global financial crisis of 2008 that has resulted in a cyclical downturn around the world, bank regulators are concerned with two major conflicting objectives. These include boosting financial intermediation that spurs economic growth or enhancing bank stability that may reduce banks' incentive to grant new loans. However, to our best knowledge, there is no previous study that examines the implication of bank competition on stability and financial intermediation simultaneously. This paper attempts to fill this gap.

As further contribution, we also examine the role of market discipline in the link between bank competition and risk. Schaeck and Cihak (2007) document the link between bank competition and market discipline through bank capitalization. In this sense, competing banks tend to behave prudently by holding higher capital ratios as a "peer disciplining tool" to gain competitive advantage. For a similar reason, in order to gain competitive advantage, banks in more competitive markets can provide better conditions that facilitate bank depositors to monitor banks than those in less competitive markets. This situation will in turn strengthen ex-post market discipline by bank depositors whenever bank risk increases or decreases via changes in bank competition.

In order to assess such issues, we focus on the Asia Pacific region for several reasons. First, the banking sector remains a major source of financing for the real sector in Asia Pacific (Adams, 2008). Second, substantial consolidations in the banking industry also occurred in Asia Pacific after the 1997 Asian crisis which may in turn affect the degree of bank competition (Soedarmono et al., 2013).

The rest of this paper is structured as follows. Aside from highlighting our research contribution, Section 2 describes prior literature on the bank competitionstability nexus, as well as the bank competition-growth nexus. Section 3 presents our data and methodology. Section 4 discusses our empirical findings and provides some robustness checks, while Section 5 concludes the paper. 


\section{Related literature}

With regards to the link between bank competition and stability, two major hypotheses have emerged in the literature, i.e. the "charter value hypothesis" and the "competition-stability hypothesis". In parallel, regarding the impact of bank competition on economic development, there are also two conflicting hypotheses, i.e. the "perfect information hypothesis" and the "asymmetric information hypothesis".

The charter value hypothesis argues that higher bank competition eroding bank charter value can contribute to higher instability due to higher bank risk taking. Keeley (1990) documents that after financial liberalization in the nineties, US banks exhibited a decline in their charter value and an increase in risk profiles. Similarly, Demsetz et al. (1996) document that US banks with higher charter value tend to have better asset quality. Levy-Yeyati and Micco (2007) also support the charter value hypothesis in the case of Latin America. In addition, Beck et al. (2006) show that the probability of banking crises in countries with a concentrated banking system is lower than in countries with a competitive banking system from a sample of 69 countries during the 1980-1997 period. Yet, Ariss (2010) has also focused on the case of developing countries and supports the charter value hypothesis.

In contrast, another strand of literature shows that higher bank competition has also a stabilizing effect when asymmetric information in loan markets is taken into consideration (Boyd and De Nicolo, 2005; Boyd et al, 2006). This is because the presence of asymmetric information in loan markets exacerbates entrepreneurial moral hazard to undertake risky projects in order to offset higher interest rates charged by banks with higher market power. Higher borrowers' risk can in turn negatively affect bank stability through a risk-shifting mechanism (Stiglitz and Weiss, 1981). This notion is often referred to as the competition-stability hypothesis. Uhde and Heimeshoff (2009) support the competition-stability hypothesis in the case of European banks, while Liu et al (2012) also find the consistent results for Southeast Asian banks. Soedarmono et al (2013) indicate that higher market power in Asian banking is associated with higher bank moral hazard, although banks hold a higher capital ratio. This finding is however reversed during the 1997 crisis period indicating that market power is necessary to prevent an increase in bank default risk in times of crisis. Using a sample of commercial 
banks in Asia Pacific as well, Fu et al. (2014) document the heterogeneous impact of bank concentration and competition on bank stability. While greater concentration fosters financial fragility, lower pricing power stemming from higher competition also results in higher bank riskiness.

While the link between bank competition and financial stability remains inconclusive, a related important issue is how bank competition affects financial intermediation and economic growth. On the one hand, the perfect information hypothesis argues that higher bank competition leads to higher economic growth because banks with higher market power tend to charge higher loan prices which may in turn preclude financial intermediation activities (Black and Strahan, 2002; Degryse and Ongena, 2005; Cetorelli and Gamberra, 2001). In a similar vein, Aysan et al. (2013) show that higher bank competition increases the outreach of banks in Turkey. Yet, Aydemir (2013) also studies the Turkish banking sector and reports that higher bank concentration exacerbates the issues of collusion in the loan market. On the other hand, the asymmetric information hypothesis states that in the presence of asymmetric information, banks with higher charter value can erode asymmetric information by investing in relationship lending activities. Relationship lending can reduce firms' financing constraints, spur loan availability and enhance economic growth (Petersen and Rajan, 1994, 1995; Berlin and Mester, 1998).

Building on these previous studies, a potential trade-off between bank stability and financial intermediation can occur along with changes in bank competition. Higher bank competition is indeed expected to boost loan growth because banks in more competitive markets tend to misprice their loan interest rates in expanding intermediation activities (Ogura, 2006). However, Foos et al (2010) provide evidence in which higher loan growth can lead to higher bank risk. In this paper, we attempt to contribute to the ongoing debate regarding the impact of bank competition on both stability and financial intermediation.

Our paper extends the literature in several directions. First, a large number of studies rely on bank concentration or Herfindahl index measures to assess the market structure of banks that influences bank market power, while our present study employs the non-structural measure of competition derived from the new industrial organization 
approach following Uchida and Tsutsui (2005) and Soedarmono et al. (2011; 2013). Second, prior studies only focus on the immediate impact of bank competition, while the present study also explores whether today's bank risk and loan growth is determined by last year's bank competition. Third, we extend the competition-stability-growth nexus by examining whether bank competition affects depositors' reaction to bank risk and hence, we embrace issues on the role of market discipline exerted by bank depositors.

Prior studies demonstrate that bank depositors indeed strongly react to bank risk. In the presence of market discipline, bank depositors require higher interest rates on their deposits or withdraw their deposits when banks take on more risk (Demirgüç-Kunt and Huizinga, 2004; Martinez-Peria and Schumkler, 2001). In this paper, our investigation regarding market discipline differs from previous studies, since we assess bank depositors' reaction to bank risk indirectly via bank competition. Because bank competition might affect bank riskness, we expect that bank depositors' reaction to bank risk is also dependent on bank competition.

\section{Data, variables and methodology}

\subsection{Data}

An unbalanced panel of annual bank-level data are retrieved from BankScope Fitch IBCA. Our dataset consists of 686 commercial banks from 12 countries in Asia Pacific from 1994 to 2009. These countries include China (103), Hong Kong (68), India (84), Indonesia (108), Malaysia (63), Sri Lanka (14), South Korea (50), Taiwan (50), Thailand (40), Pakistan (34), Philippines (39), and Vietnam (33) ${ }^{2}$. Moreover, countryspecific data are also taken from various sources. These include the International Financial Statistics (IFS) established by the International Monetary Fund, the World Bank Financial Structure Dataset established by Beck and Demirgüç-Kunt (2009), as well as the economic freedom index at the country level coming from Heritage Foundation. All country-specific data other than the economic freedom index (ECOFREE) come from the IFS. ECOFREE comes from Heritage Foundation.

\footnotetext{
2 The number of banks in each country is shown in parentheses. In the meantime, our sample could suffer from a survival bank bias because some banks that have failed are not necessarily present throughout our entire sample period, particularly after they default. Nevertheless, because we use panel data techniques and because we have not eliminated the observations on banks that have failed prior to their default this should be less of a concern.
} 


\subsection{Variables}

\subsubsection{Dependent variables}

Bank loan growth is used to assess financial intermediation. Let $i$ and $t$ represent bank index and time index, respectively. Following Bouvatier and Lepetit (2008), we define bank loan growth as follows:

$$
\operatorname{DLOAN}_{i, t}=\left(L_{i, t}-L_{i, t-1}\right) / 0.5\left(T A_{i, t}+T A_{i, t-1}\right)
$$

$L$ is banks' total loans in million US dollar, while $T A$ is banks' total assets in million US dollar. For robustness considerations, we also consider another measure of bank loan growth, which is the annual growth rate of total loans (LOANG).

In the meantime, we use credit risk and income volatility measures to assess bank stability. Credit risk is defined as the ratio of loan loss provisions to total loans $(L L P)$, while income volatility is the standard deviation of the return on assets computed from a three-period rolling window (SDROA). In other words, the standard deviation of return on assets at time $t$ is calculated based on the return on assets from time $t$ to $t-2$.

Finally, in order to measure how bank depositors react to bank risk, we use the following measure where $D$ is bank total deposits in million US dollar.

$$
D_{D E P O}{ }_{i, t}=\left(D_{i, t}-D_{i, t-1}\right) / 0.5\left(T A_{i, t}+T A_{i, t-1}\right)
$$

Alternatively, we consider the annual growth rate of total deposits (DEPOG) as in Martinez-Peria and Schmukler (2001).

\subsubsection{Bank competition}

In order to assess bank competition, we construct the Lerner index derived from the industrial organization approach. Specifically, we follow Uchida and Tsutsui (2005) that modify the non-structural measure of competition derived from Bresnahan (1982) and applied to Japanese banks. The merit of this measure is that it does neither require any assumption on the equilibrium of the banking market as in Panzar and Rosse (1987), nor the market structure of each bank which can be different across banks, even for 
similar types of banks. Moreover, the non-structural measure of bank competition can be computed easily using indicators from banks' financial statements. Hence, the degree of bank competition at the country level is reflected by the average capacities of banks for each country in pricing their products above marginal cost. Using a panel data methodology, Uchida and Tsutsui's (2005) method can also capture changes in the degree of competition from one period to the other.

Likewise, the aggregate index of bank market power derived by Uchida and Tsutsui (2005) is already used in previous studies related to Asian banks. These include Soedarmono et al. (2011) and Soedarmono et al. (2013). Specifically, the degree of bank competition is computed using the system of equations as follows:

$$
\begin{aligned}
\ln C_{i t}= & b_{0}+b_{1} \overline{\ln q_{i t}}+\frac{1}{2} b_{2}\left(\overline{\ln q_{i t}}\right)^{2}+b_{3} \overline{\ln d_{i t}}+\frac{1}{2} b_{4}\left(\overline{\ln d_{i t}}\right)^{2}+b_{5} \overline{\ln w_{i t}}+\frac{1}{2} b_{6}\left(\overline{\ln w_{i t}}\right)^{2} \\
& +b_{7}\left(\overline{\ln q_{i t}}\right)\left(\overline{\ln w_{i t}}\right)+b_{8}\left(\overline{\ln q_{i t}}\right)\left(\overline{\ln d_{i t}}\right)+b_{9}\left(\overline{\ln d_{i t}}\right)\left(\overline{\ln w_{i t}}\right)+e_{i t}^{C} \\
R_{i t}= & \frac{\theta_{t}}{\eta_{t}} R_{i t}+r_{i t} q_{i t}+c_{i t}\left(b_{1}+b_{2}\left(\overline{\ln q_{i t}}\right)+b_{7}\left(\overline{\ln w_{i t}}\right)+b_{8}\left(\overline{\ln d_{i t}}\right)\right) \\
& +C_{i t} \frac{q_{i t}}{d_{i t}}\left(b_{3}+b_{4}\left(\overline{\ln d_{i t}}\right)+b_{8}\left(\overline{\ln q_{i t}}\right)+b_{9}\left(\overline{\ln w_{i t}}\right)\right)+e_{i t}^{S} \\
\ln p_{i t}= & g_{0}-(1 / \eta) \ln q_{i t}+g_{1} \ln G D P G_{t}+g_{2} \ln I R_{t}+g_{3} \ln T A_{i t}+e_{i t}^{D}
\end{aligned}
$$

Each variable with bars represents a deviation from its cross-sectional mean in each time period. Bank competition for each year is represented by $\theta_{t} \in[0,1]$ depicting the conjectural variations of elasticity of total banking industry outputs with respect to the output of bank $i$. In the case of perfect competition, $\theta_{t}=0$; under pure monopoly, $\theta_{t}=1$; and finally, $\theta_{t}<0$ implies pricing below marginal cost.

Moreover, $C_{i t}$ is defined by total expenses, $q_{i t}$ by total earning assets, $d_{i t}$ by total deposits and short-term funding, $w_{i t}$ by the ratio of operating expenses to total assets, $R_{i t}$ by total revenue, $r_{i t}$ by the ratio of interest expenses to total deposits, $p_{i t}$ by the ratio of total revenue to total earning assets. $G D P G_{t}, I R_{t}$ and $T A_{i t}$ are factors that affect the 
demand for loans, defined as the growth of real gross domestic product $(G D P)$, the shortterm interest rate, and bank total assets, respectively.

To estimate System (1), country-level estimations are conducted and we use the Seemingly Unrelated Regression (SUR) method. Moreover, $\theta_{t}$ is estimated by annual time dummy variables and $\eta$ by bi-annual time dummy variables (every two years), because $\eta$ values are linearly dependent on the time-specific variables (GDPG and $I R)$. Eventually, $\theta_{t}$ denotes the Lerner index of the banking industry in each country over time (LERNER). Hence, higher LERNER is associated with higher market power (or lower competition) in the banking industry.

\subsubsection{Control variables}

Several bank-specific control variables are incorporated in this study. First, we consider the banks' total capital adequacy ratio $(C A R)$, because bank capital ratios admittedly affect lending behaviour which may lead to "capital crunch" problems (Bernanke and Lown, 1991; Peek and Rosengren, 1995). Second, we incorporate the ratio of total deposits to total assets (DEPO) as a control variable which directly affects deposit growth (DDEPO or DEPOG). Third, another source of loan growth and bank risk is the extent to which banks engage in non-interest income activities. In particular, banks engaging in fee and commission-based income can underprice loans and hence, granting loans at a lower cost in order to sell other fee-based products to their customers (Lepetit et al., 2008). This may in turn foster loan growth, but underestimated credit risk may erode bank stability. To account for non-interest income activities, we incorporate the ratio of non-interest income to total revenue $(N N I)$ as a control variable. Furthermore, bank size (SIZE) measured by the logarithm of banks' total assets is also considered control variable because larger bank size tends to exacerbate bank risk taking (Mishkin, 2006) and to some extents, larger banks are subject to greater market discipline (Demirgüç-Kunt and Huizinga, 2011).

Aside from bank-specific factors, we also consider country-specific factors as control variables. We specifically include the inflation rate $(I N F)$, the growth rate of real per capita gross domestic product $(G D P G)$, the degree of economic freedoms 
(ECOFREE), and the foreign exchange reserves growth rate (FOREXG) to control for various country-specific characteristics, such as economic development, institutional quality, macroeconomic stability, and so on.

\subsection{Methodology}

In terms of econometric methodology, we use a dynamic panel data model because loan growth, risk and deposit growth in banking vary over time. Arguably, their current values at time $t$ are also more likely to be dependent on their value at time $t-1$. Based on the nature of these dependent variables, the use of dynamic panel data methodology is relevant. Dynamic panel data models that account for the one year-lagged value of dependent variable as control variable, and that are able to endogenize several explanatory variables are again appropriate to cope with reverse causality problems. Dynamic panel data models are also appropriate to analyze both the short-run and longrun effects of explanatory variables on dependent variables.

To estimate our dynamic panel data models, we use the two-step Generalized Method of Moments (GMM) estimations following Arellano and Bover (1995) and Blundell and Bond (1998). This method is also referred to as the system GMM. The system GMM is essentially an extension of the standard GMM developed by Arellano and Bond (1991). Arellano and Bond (1991) only consider the first difference of each variable in the regressions, while the lagged levels of explanatory variables are used as instruments. The use of the lagged levels as instruments may be inappropriate, particularly when variables are close to a random walk. To overcome this shortcoming, Arellano and Bover (1995) and Blundell and Bond (1998) develop the system GMM to improve the standard GMM by introducing the levels equation to produce a system of two equations consisting of the levels equation itself and the first-differenced equation. Hence, lagged differences of the explanatory and dependent variables can be valid instruments for the levels equation. Eventually, Baltagi (2005) proves that the system GMM produces more efficient and precise estimates than the Standard GMM.

In this meantime, our explanatory variable of interest is the degree of bank competition (LERNER). Given the possibility that banks do not immediately respond to 
changes in market power, it is also worth examining whether bank market power after a

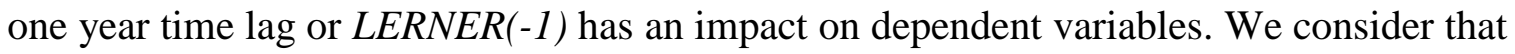
LERNER and LERNER(-1) as predetermined variables, because both variables are estimated using the SUR method based on a system of three equations as shown in System (1). Hence, LERNER and LERNER(-1) can contain measurement error and thus, need to be instrumented.

We also consider $C A R$ as a predetermined variable, because bank capital management is not strictly exogeneous, because it depends on banks' managerial discretion, and bank-specific and country-specific characteristics. Finally, we also consider $G D P G$ as a predetermined variable, because the real per capita income growth is dependent on various factors, including bank market power (Fernandez et al, 2010).

Given that our models contains an autoregressive variable, we then use the orthogonal deviations transformation of instrumental variables in order to take crosssection fixed effects into account. Considering bank-level fixed effects is an important dimension because our bank sample is heterogeneous and comes from different countries with different macroeconomic, institution and regulatory environments. We further include time dummies in our models to account for time fixed-effects. Yet, we also take into account Windmeijer's (2005) finite sample correction to ensure that our estimates are robust. Finally, we verify the validity of our dynamic panel data models using $A R$ (2) test and Hansen-J test. The GMM model is valid when the AR (2) test and the Hansen-J test are both not significant and hence, showing that there is no second order serial correlation among errors of first-differenced equation, and that our identifying restrictions are valid, respectively.

\section{Empirical results}

To accurately conduct our empirical investigation, we initially eliminate values which are higher than 1 and smaller than 0 for $C A R$, DEPO, and NNI. Table 1 presents the descriptive statistics of all the "clean" variables used in this study. Moreover, Table 2 presents the correlation structure of such variables. As no notable correlation can be found between all independent variables considered in this study, multicollinearity issues are therefore less likely to occur. 
[Insert Table 1 and Table 2 here]

\subsection{Bank competition and loan growth}

Since banks operate in a more competitive market, they tend to boost loans by setting lower loan prices to attract new borrowers (Ogura, 2006). Prior literature also suggests that higher degree of bank competition boosts small businesses development, as borrowing costs decline (Degryse and Ongena, 2005; Cetorelli and Gamberra, 2001). Building on these papers, we focus our investigation on the impact of bank market power on loan growth as a proxy of financial intermediation.

In Table 3, we highlight that banks in less competitive markets (higher LERNER) tend to reduce loan growth (DLOAN or $L O A N G)$. Our findings are thus consistent with the perfect information hypothesis arguing that higher bank competition leads to higher economic growth, because banks in less competitive markets tend to charge higher loan interest rates which may in turn preclude financial intermediation (Black and Strahan, 2002; Degryse and Ongena, 2005; Cetorelli and Gamberra, 2001). We further notice that $D L O A N$ and $L O A N G$ equations are both valid, because both the AR (2) test and the Hansen-J test are not significant.

[Insert Table 3 here]

As a robustness check, we exclude banks operating in China and South Korea from our sample. Indeed, Chinese banks have been highly regulated since the aftermath of the 1997 Asian crisis and thus, policies aiming at encouraging competition in banking has been a challenging process. Similarly, the South Korean banking system was also relatively uncompetitive and severely affected by the 1997 Asian crisis (Kataoka, 1999). During the 1997 Asian crisis, there are at least 14 Korean banks that failed simultaneously. In order to exclude the special characteristics of these two countries, we therefore run estimations without Chinese banks and South Korean banks. Table 4 presents empirical results for this purpose. Specifically, the negative link between 
LERNER and loan growth (DLOAN or LOANG) is not altered. Yet, all the GMM models shown in Table 4 are also valid because the AR(2) and Hansen-J test are both not significant.

[Insert Table 4 here]

Several insights can be drawn from these findings. Banks in less competitive markets indeed tend to have higher market power which enables them to increase their lending rates. Although this behavior decreases financial intermediation and hampers economic growth, this behavior might also due to the fact that banks in less competitive markets are more prudent than those in competitive markets because of the fear of losing their franchise (the charter value hypothesis). In other words, for banks in less competitive markets, greater market power acts as a self-disciplining factor that limits excessive risk taking. Accordingly, credit risk might be priced appropriately, which unfortunately leads to higher lending rates and lower loan growth.

If we consider the presence of asymmetric information in loan markets, entrepreneurs who obtain loans can respond to higher loan pricing by running riskier projects to offset higher lending rates. Higher entrepreneurs' moral hazard can therefore exacerbate bank riskiness through risk-shifting mechanisms (Stiglitz and Weiss (1981). On the contrary, in the absence of asymmetric information, bank riskiness will decline with higher $L E R N E R$, as long as banks in less competitive markets do not underestimate risk and set up lending rates appropriately, albeit reducing loan growth afterward. In the following section, we investigate the impact of LERNER on bank riskiness in order to verify whether the negative link between LERNER and bank loan growth (DLOAN or $L O A N G)$ is presumably characterized by the presence of asymmetric information.

\subsection{Bank competition and risk}

In Table 3 and Table 4, we also document our empirical results on the nexus between $L E R N E R$ and bank risk measured by credit risk $(L L P)$ and income volatility (SDROA). We find that higher LERNER is associated with higher LLP and SDROA regardless of whether or not we exclude Chinese and South Korean banks from our 
sample. This suggests that banks in less competitive markets tend to have higher credit risk and income volatility. Accordingly, the immediate adverse impact of market power on bank stability is also apparent in Soedarmono et al (2011 \& 2013), although they apply a static panel data model.

Nevertheless, the positive link between LERNER and bank credit risk (LLP) is reversed when we consider the impact of $L E R N E R$ at time $t-1$. In other words, although higher LERNER immediately increases bank credit risk, higher LERNER may also reduce

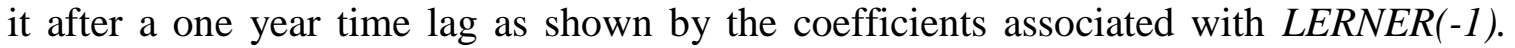
Given that our purpose is to assess how bank competition affects both stability and

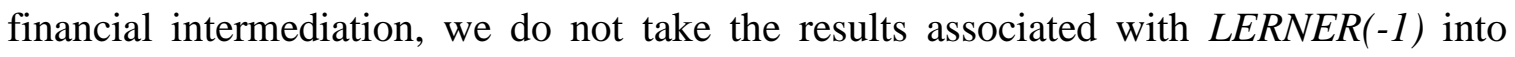
close consideration, because $\operatorname{LERNER(-1)}$ does not affect bank loan growth (DLOAN or $L O A N G)$.

Combining the results regarding the competition-growth nexus, as well as the competition-stability nexus, we show that although banks in less competitive markets reduce loan growth, such a reduction is not sufficient to improve their stability. Hence, as mentioned earlier, asymmetric information problems are more likely to exist exacerbating entrepreneurs' moral hazard which in turn might increase the riskiness of banks in less competitive markets.

\subsection{Bank competition and market discipline}

Since higher market power in banking leads to lower loan growth but higher instability in Asian banks, it is worth examining whether such instability can be mitigated by market discipline. In this section, we are particularly interested in the role played by bank depositors in facing higher bank riskiness. Market discipline is indeed of particular interest for bank regulators and it has been further emphasized in the new Basel accords.

From Table 3 and Table 4, we observe that the link between LERNER and deposit growth (DDEPO and $D E P O G$ ) is negative and significant. This indicates that banks in less competitive markets experience lower deposit growth. Given that banks in less competitive markets (higher LERNER) tend to exhibit higher credit risk and income volatility as discussed in the previous section, our results show that bank depositors are indeed sensitive to higher bank risk along with an increase in market power in banking. 
Yet, our GMM models for $D D E P O$ and $D E P O G$ equations are valid because $A R(2)$ test and Hansen-J test are both insignificant.

In Table 3 and Table 4 as well, we also document a positive link between $\operatorname{LERNER(-1)}$ and deposit growth. This positive link is due to the fact that $\operatorname{LERNER(-1)}$ exhibits a negative impact on bank credit risk. As bank credit risk declines due to greater market power in banking after a one year time lag, bank depositors also react positively by increasing deposit growth.

Overall, we show that market discipline indeed exists in Asian banks due to different characteristics of market power in the banking industry. For banks operating in less competitive market, deposit growth declines in response to higher market power in banking. However, deposit growth can also increase along with greater market power in banking (lower competition), particularly after a one year time lag.

\subsection{Additional robustness checks}

To this end, because the number of banks in our sample differs substantially from country to country, we also perform Weighted Least Squares (WLS) estimations in order to ensure that our results are not subject to sample bias affected by countries with a large number of banks. In conducting the WLS estimations, we incorporate time dummies, but not individual fixed effects, because individual fixed effects cannot be included in WLS estimations (Hoechle, 2007). Table 5 presents our results using the WLS estimation for banks from the 12 countries considered in this study, while Table 6 presents the similar results without incorporating banks from China and South Korea. Overall, our main results discussed earlier are not substantially altered.

[Insert Table 5 and 6 here]

\section{Conclusion}

This paper aims to highlight the effect of bank competition on financial intermediation and bank riskiness. Our findings strongly emphasize the negative link between market power in banking and bank loan growth as a proxy of financial intermediation. Market power is also positively associated with bank instability measured 
by credit risk and income volatility. Banks in less competitive markets are indeed more unstable and contribute less than those in more competitive markets to strengthen financial intermediation. This study further highlights the role of market discipline exerted by bank depositors. As market power in banking results in higher instability, bank depositors in less competitive markets tend to deposit lower amounts. Overall, our results are robust to model specification.

To a lesser extent, we also show that the link between bank competition, risk taking and deposit growth might be altered when we consider the one-year-lagged value of bank competition. Specifically, although greater market power in the banking industry can immediately lead to higher instability and lower deposit growth, greater market power can also reduce bank riskiness and increase deposit growth after a one year time lag. We therefore highlight that the charter value hypothesis and the competition-stability hypothesis might be in place simultaneously depending on whether we consider the immediate or longer run implication of bank competition. Yet, we further highlight that whatever the impact of competition on bank riskiness, the role of market discipline exerted by bank depositors remains important. As bank market power increases (reduces) instability, bank deposit growth declines (increases).

In addition, our results regarding the impact of bank competition on financial intermediation and deposit growth do not support the theoretical model by Park and Pennacchi (2009) in which greater bank competition due to market-extension mergers (acquisitions involving two banks in different markets) can help borrowers, but harm

depositors. In our study, greater bank competition is beneficial to both bank borrowers and depositors simultaneously at least in the short run.

\section{References}

Adams, C., 2008. Emerging East Asian banking system: Ten years after the 1997/98 crisis. ADB Working Paper Series on Regional Economic Integration No.16

Arellano, M., Bover, O., 1995. Another look at the instrumental variable estimation of error-component models. Journal of Econometrics 68, 29-51. 
Arellano, M., Bond, S., 1991. Some tests of specification for panel data: Monte Carlo evidence and an application to employment equations. Reviews of Economic Studies 58, 277-297.

Ariss, R.T., 2010. On the implications of market power in banking: Evidence from developing coutnries. Journal of Banking and Finance 34 (4), 765-775

Aydemir, R., 2013. Competition and collution in the Turkish banking industry. Emerging Markets Finance and Trade 49(5), 31-40

Aysan, A.F., Disli, M., Schoors, K., 2013. Bank competition and outreach: Evidence from Turkey. Emerging Markets Finance and Trade 49(5), 7-30

Baltagi, B.H., 2005. Econometric Analysis of Panel Data, third ed. John Wiley \& Sons Ltd., Chichester.

Beck, T., Demirgüç-Kunt, A., 2009. Financial institutions and markets across countries and over time: Data and analysis. Working paper series, 4943, World Bank, Washington, DC

Beck, T., Dermirguc-Kunt, A., Levine, R., 2006. Bank concentration, competition and crises: First results. Journal of Banking and Finance 30, 1581-1603

Berlin, M., Mester, L.J., 1998. On the Profitability and Cost of Relationship Lending. Journal of Banking and Finance 22, 873-897

Bernanke, B. S., Lown, C. S., 1991. Credit crunch. Brookings Papers on Economic Activity 2, 205-47.

Black, S.E., Strahan, P., 2002. Entrepreneurship and bank credit availability. Journal of Finance 57(6), 2807-2833

Blundell, R., Bond, S., 1998. Initial conditions and moment restrictions in dynamic panel data models. Journal of Econometrics 87, 115-143.

Bouvatier, V., Lepetit, L., 2008. Banks' procyclical behaviour: does provisioning matter? Journal of International Financial Markets, Institutions and Money 18, 513-526.

Boyd, J.H., De Nicolo, G., 2005. The theory of bank risk taking and competition revisited. Journal of Finance 60, 1329-1343

Boyd, J.H., De Nicolo, G., Jalal, A.M., 2006. Bank risk-taking and competition revisited: new theory and new evidence. Working paper series 06/297, International Monetary Fund, Washington, DC

Bresnahan, T.F. 1982. The oligopoly solution concept is identified. Economics Letters 
$10,87-92$

Cetorelli, N., Gambera, M., 2001. Banking market structure, financial dependence and growth: International evidence from industry data. Journal of Finance 56, 617-648

Degryse, H., Ongena, S., 2005. Distance, lending relationships and competition. Journal of Finance 60, 231-266

Demirgüç-Kunt, A., Huizinga, H., 2011. Do we need large banks? Evidence on performance, strategy and market discipline. European Banking Center Discussion Paper No.005.

Demirgüç-Kunt, A., Huizinga, H., 2004. Market discipline and deposit insurance. Journal of Monetary Economics 51, 375-399.

Demsetz, R.S., Saidenberg, M.R., Strahan, P.E., 1996. Banks with something to lose: the disciplinary role of franchise value. Economic Policy Review, 1-14

Fernandez, A.I., González, F., Suarez, N., 2010. How institutions and regulation shape the influence of bank concentration on economic growth: International evidence. International Review of Law and Economics 30 (1), 28-36

Foos, D., Norden, L., Weber, M., 2010. Loan growth and riskiness of banks. Journal of Banking and Finance 34(12), 2929-2940.

Fu, X., Lin., Y., Molyneux., P., 2014. Bank competition and financial stability in Asia Pacific. Journal of Banking and Finance 38, 64-77.

Hoechle, D., 2007. Robust standard errors for panel regressions with cross-sectional dependence. The Stata Journal 7(3), 281-312.

Keeley, M.C., 1990. Deposit insurance, risk and market power in banking. American Economic Review 80(5), 1183-1200

Lepetit, L., Nys, E., Rous, P., Tarazi, A., 2008. The expansion of services in European banking: Implications for loan pricing and net interest margins. Journal of Banking and Finance 32(11), 2325-2335

Levy-Yeyati, E., Micco, A. 2007. Concentration and foreign penetration in Latin American banking sectors: Impact on competition and risk. Journal of Banking and Finance 31, 1633-1647

Liu, H., Nguyen, L. and Molyneux, P. (2012) Competition and risk in South East Asian commercial banking. Applied Economics 44, 3627-3644 
Martinez-Peria, M.S., Schmukler, S.L., 2001. Do depositors punish banks for bad behavior? Market discipline, deposit insurance and banking crises. Journal of Finance $56,1029-1051$.

Mishkin, F.S., 2006. How big a problem is too big to fail? Journal of Economic Literature 44, 988-1004.

Ogura, Y., 2006. Learning from a rival bank and lending boom. Journal of Financial Intermediation 15, 535-555.

Park, K., Pennachhi, G., 2009. Harming depositors and helping borrowers: The disparate impact of bank consolidation. Review of Financial Studies 22(1), 1-40.

Panzar, J.C., Rosse, J.N., 1987. Testing for 'monopoly' equilibrium. Journal of Industrial Economics 35 (4), 443-456.

Peek, J., Rosengreen, E., 1995. The capital crunch: Neither a borrower nor a lender be. Journal of Money, Credit and Banking 27 (3), 625-638

Petersen, M. A., Rajan, R.G., 1994. The benefits of lending relationships: Evidence from small business data. Journal of Finance 49, 1367-1400.

Petersen, M. A., Rajan, R.G., 1995. The effect of credit market competition on lending relationships. Quarterly Journal of Economics 110, 407-443

Schaeck, K., Cihak, M., 2007. Banking competition and capital ratios. Working paper series, 07/216, International Monetary Fund, Washington, DC

Soedarmono, W., Machrouh, F., Tarazi, A., 2013. Bank competition, crisis and risk taking: Evidence from emerging markets in Asia. Journal of International Financial Markets, Institutions and Money 23, 196-221

Soedarmono, W., Machrouh, F., Tarazi, A., 2011. Bank market power, economic growth and financial stability: Evidence from Asian banks. Journal of Asian Economics 22(6), 460-470

Stiglitz, J., Weiss, A., 1981. Credit rationing with imperfect information. American Economic Review 71, 393-410

Uchida, H., Tsutsui, Y., 2005. Has competition in the Japanese banking sector improved? Journal of Banking and Finance 29, 419-439

Uhde, A., Heimeshoff, U., 2009. Consolidation in banking and financial stability in Europe: Empirical evidence. Journal of Banking and Finance 33, 1299-1311 
Windmeijer, F., 2005. A finite sample correction for the variance of linear efficient twostep GMM estimators. Journal of Econometrics 126, 25-51 
Table 1. Descriptive statistics

\begin{tabular}{|c|c|c|c|c|c|}
\hline Variable & Definition & Mean & Std. Dev. & Min & Max \\
\hline \multicolumn{6}{|l|}{ Lerner } \\
\hline$Q$ & Total earning assets (million USD) & 12359.5 & 58044.65 & 0.126 & $1.44 \mathrm{E}+06$ \\
\hline$\vec{C}$ & Total expenses (million USD) & 90240.113 & 529468.45 & 0.013 & 13897949 \\
\hline$D$ & Total deposits and short term funding (million USD) & 10535.445 & 54044.344 & 0.002 & 1431017.9 \\
\hline$R$ & Total revenue (million USD) & 75003.77 & 483640.2 & -2754.779 & 13897949 \\
\hline$W$ & Ratio of total operating expenses to total assets & 0.023908 & 0.024928 & $1.65 \mathrm{E}-04$ & 0.878493 \\
\hline$R$ & Ratio of interest expenses to total deposits & 0.10337 & 0.21097 & $1.52 \mathrm{E}-02$ & 8.5098 \\
\hline$P$ & Ratio of total revenue to total earning assets & 13.52625 & 32.28294 & -1.277457 & 675.2431 \\
\hline$I R$ & Annual short-term interest rate & 0.07779 & 0.07444 & 0.0007 & 0.6279 \\
\hline \multicolumn{6}{|c|}{ Explanatory var. } \\
\hline LERNER & Lerner index (Lerner index) & 0.0534 & 0.52399 & -0.98699 & 1.92911 \\
\hline SIZE & Logarithm of bank total assets & 7.48835 & 2.01198 & -1.09961 & 14.36128 \\
\hline DEPO & Ratio of total deposits to total assets & 0.72574 & 0.19381 & 0.00003 & 0.99655 \\
\hline$C A R$ & Total capital adequacy ratio & 0.16454 & 0.11255 & 0.005 & 0.915 \\
\hline$N N I$ & Ratio of non-net interest revenue to total revenue & 0.21961 & 0.20513 & 0.00007 & 0.99848 \\
\hline$I N F$ & Inflation rate & 0.06067 & 0.05901 & -0.03947 & 0.5802 \\
\hline$G D P G$ & Real per capita GDP growth rate & 0.05514 & 0.03393 & -0.13127 & 0.14195 \\
\hline ECOFREE & Economic freedom index & 0.61457 & 0.12189 & 0.386 & 0.905 \\
\hline FOREXG & Foreign exchange reserves growth rate & 0.2002 & 0.29048 & -0.68859 & 1.63632 \\
\hline \multicolumn{6}{|c|}{ Dependent var. } \\
\hline DLOAN & Loan growth rate & 0.0670373 & 0.4585605 & -1.968385 & 2 \\
\hline$L O A N G$ & Actual loan growth rate & 0.1339544 & 0.3200161 & -1.981694 & 1.963238 \\
\hline$L L P$ & Ratio of loan loss provisions to total loans & 0.0193369 & 0.051427 & 0.0000136 & 0.9486932 \\
\hline SDROA & Standard deviation of ROA from time $t$ to $t-2$ & 0.0067533 & 0.0105557 & 0.0000055 & 0.0748714 \\
\hline$D D E P O$ & Deposit growth rate & 0.09762 & 0.1944373 & -1.138423 & 1.569936 \\
\hline$D E P O G$ & Actual deposit growth rate & 0.184506 & 0.3865803 & -0.9979501 & 3.089286 \\
\hline
\end{tabular}


Table 2. Correlation structure of all variables

\begin{tabular}{|c|c|c|c|c|c|c|c|}
\hline Variables & DLOAN & $L O A N G$ & $L L P$ & SDROA & $D D E P O$ & $D E P O G$ & LERNER \\
\hline DLOAN & 1 & & & & & & \\
\hline$L O A N G$ & 0.9023 & 1 & & & & & \\
\hline$L L P$ & -0.2901 & -0.2424 & 1 & & & & \\
\hline SDROA & -0.1907 & -0.1318 & 0.3631 & 1 & & & \\
\hline DDEPO & 0.6966 & 0.6675 & -0.1571 & -0.129 & 1 & & \\
\hline$D E P O G$ & 0.6149 & 0.6355 & -0.1122 & -0.0492 & 0.8738 & 1 & \\
\hline LERNER & -0.0235 & -0.0374 & 0.0322 & 0.0382 & -0.0971 & -0.0233 & 1 \\
\hline$C A R$ & -0.0931 & -0.0363 & 0.1321 & 0.0951 & -0.0821 & 0.0114 & 0.0219 \\
\hline DEPO & -0.0045 & -0.0004 & -0.0483 & -0.0383 & 0.1925 & 0.0138 & -0.1957 \\
\hline$N N I$ & -0.0511 & -0.0388 & 0.0094 & -0.0585 & -0.019 & 0.033 & 0.2417 \\
\hline SIZE & 0.0517 & -0.0061 & -0.1618 & -0.1797 & 0.0146 & -0.0502 & 0.1495 \\
\hline ECOFREE & -0.194 & -0.2217 & -0.0009 & 0.0563 & -0.2128 & -0.1572 & 0.184 \\
\hline$I N F$ & 0.175 & 0.1626 & -0.058 & -0.0863 & 0.137 & 0.1543 & 0.3331 \\
\hline$G D P G$ & 0.1351 & 0.106 & -0.1521 & -0.1603 & 0.0946 & 0.0834 & 0.2193 \\
\hline FOREXG & 0.2243 & 0.1954 & 0.0268 & -0.0742 & 0.3167 & 0.2437 & -0.1171 \\
\hline
\end{tabular}

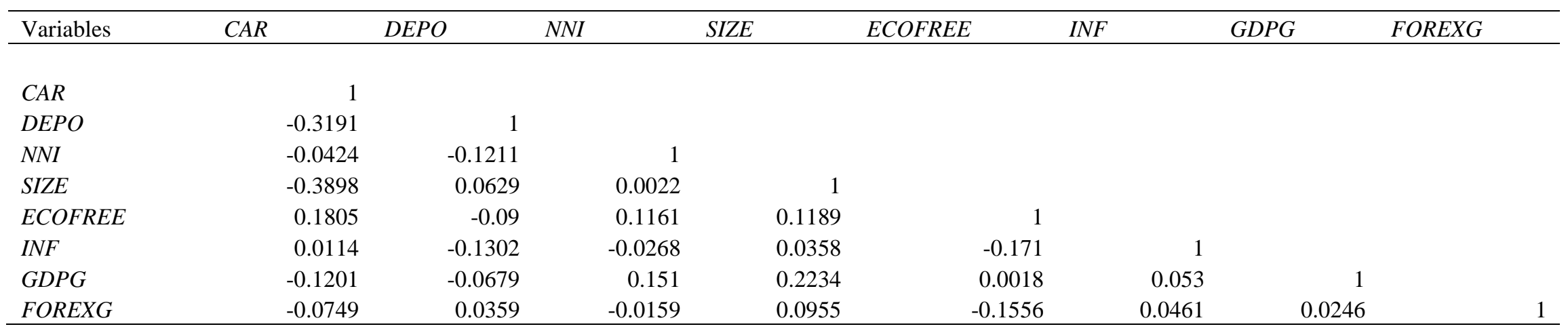


Table 3. Empirical results from the System GMM estimation for all countries. (***), (**), and (*) indicate significance at the $1 \%, 5 \%$ and $10 \%$ levels, respectively. Standard errors are in parentheses.

\begin{tabular}{|c|c|c|c|c|c|c|}
\hline \multirow[b]{2}{*}{ Explanatory Variables } & \multicolumn{2}{|c|}{ Loan growth } & \multicolumn{2}{|c|}{ Risk } & \multicolumn{2}{|c|}{ Market discipline } \\
\hline & $D L O A N$ & $L O A N G$ & LLP & SDROA3 & $D D E P O$ & $D E P O G$ \\
\hline$D E P . V A R(-1)$ & $\begin{array}{l}-0.06716 * * \\
(0.029)\end{array}$ & $\begin{array}{l}0.17189 * * * \\
(0.039)\end{array}$ & $\begin{array}{l}0.13477 * * * \\
(0.042)\end{array}$ & $\begin{array}{l}0.65190 * * * \\
(0.031)\end{array}$ & $\begin{array}{l}0.04383 \\
(0.034)\end{array}$ & $\begin{array}{l}0.08996 * * * \\
(0.034)\end{array}$ \\
\hline LERNER & $\begin{array}{l}-0.04018^{*} \\
(0.023)\end{array}$ & $\begin{array}{l}-0.12169 * * * \\
(0.038)\end{array}$ & $\begin{array}{l}0.02411 * * * \\
(0.008)\end{array}$ & $\begin{array}{l}0.00156^{*} \\
(0.001)\end{array}$ & $\begin{array}{l}-0.08954 * * * \\
(0.025)\end{array}$ & $\begin{array}{l}-0.12437 * * * \\
(0.047)\end{array}$ \\
\hline $\operatorname{LERNER(-1)}$ & $\begin{array}{l}0.02396 \\
(0.021)\end{array}$ & $\begin{array}{l}0.07020 \\
(0.036)\end{array}$ & $\begin{array}{l}-0.01250 * \\
(0.007)\end{array}$ & $\begin{array}{l}0.00056 \\
(0.001)\end{array}$ & $\begin{array}{l}0.05423 * * \\
(0.024)\end{array}$ & $\begin{array}{l}0.09405^{* * *} \\
(0.045)\end{array}$ \\
\hline$C A R$ & $\begin{array}{l}-0.00364 \\
(0.003)\end{array}$ & $\begin{array}{l}0.00249 \\
(0.004)\end{array}$ & $\begin{array}{l}0.03878 \\
(0.034)\end{array}$ & $\begin{array}{l}-0.00059 * * * \\
(0.000)\end{array}$ & $\begin{array}{l}-0.00001 \\
(0.002)\end{array}$ & $\begin{array}{l}-0.00586 \\
(0.005)\end{array}$ \\
\hline$D E P O$ & $\begin{array}{l}-0.00771 \\
(0.031)\end{array}$ & $\begin{array}{l}0.09844 * * \\
(0.043)\end{array}$ & $\begin{array}{l}0.00509 \\
(0.007)\end{array}$ & $\begin{array}{l}-0.00014 \\
(0.001)\end{array}$ & $\begin{array}{l}0.24122 * * * \\
(0.026)\end{array}$ & $\begin{array}{l}0.13799 * * \\
(0.055)\end{array}$ \\
\hline$N N I$ & $\begin{array}{l}-0.11075 \\
(0.074)\end{array}$ & $\begin{array}{l}-0.02127 \\
(0.127)\end{array}$ & $\begin{array}{l}0.01289 * \\
(0.007)\end{array}$ & $\begin{array}{l}-0.00924 * * * \\
(0.003)\end{array}$ & $\begin{array}{l}0.05321 \\
(0.074)\end{array}$ & $\begin{array}{l}-0.01337 \\
(0.153)\end{array}$ \\
\hline$S I Z E$ & $\begin{array}{l}-0.00382 \\
(0.035)\end{array}$ & $\begin{array}{l}-0.00462 \\
(0.049)\end{array}$ & $\begin{array}{l}-0.00125^{*} \\
(0.001)\end{array}$ & $\begin{array}{l}0.00484 * * * \\
(0.001)\end{array}$ & $\begin{array}{l}0.06443 * * \\
(0.032)\end{array}$ & $\begin{array}{l}0.10148 \\
(0.070)\end{array}$ \\
\hline ECOFREE & $\begin{array}{l}0.18588 * * * \\
(0.054)\end{array}$ & $\begin{array}{l}0.35826 * * * \\
(0.088)\end{array}$ & $\begin{array}{l}-0.01261 * \\
(0.007)\end{array}$ & $\begin{array}{l}-0.00327 * \\
(0.002)\end{array}$ & $\begin{array}{l}0.22309 * * * \\
(0.063)\end{array}$ & $\begin{array}{l}0.43847 * * * \\
(0.129)\end{array}$ \\
\hline$I N F$ & $\begin{array}{l}0.50029 * * * \\
(0.123)\end{array}$ & $\begin{array}{l}0.62505 * * * \\
(0.188)\end{array}$ & $\begin{array}{l}-0.02300 * * \\
(0.009)\end{array}$ & $\begin{array}{l}-0.00636 \\
(0.005)\end{array}$ & $\begin{array}{l}0.61023 * * * \\
(0.124)\end{array}$ & $\begin{array}{l}0.83569 * * * \\
(0.236)\end{array}$ \\
\hline$G D P G$ & $\begin{array}{l}-0.00169 * * * \\
(0.000)\end{array}$ & $\begin{array}{l}-0.00237 * * * \\
(0.001)\end{array}$ & $\begin{array}{l}-0.08887 * * * \\
(0.023)\end{array}$ & $\begin{array}{l}0.00003 * * \\
(0.000)\end{array}$ & $\begin{array}{l}-0.00113 \text { *** } \\
(0.000)\end{array}$ & $\begin{array}{l}-0.00164 * * \\
(0.001)\end{array}$ \\
\hline FOREXG & $\begin{array}{l}0.09053 * * * \\
(0.017)\end{array}$ & $\begin{array}{l}0.13994 * * * \\
(0.025)\end{array}$ & $\begin{array}{l}0.00774 * * * \\
(0.003)\end{array}$ & $\begin{array}{l}-0.00019 \\
(0.001)\end{array}$ & $\begin{array}{l}0.17341 * * * \\
(0.017)\end{array}$ & $\begin{array}{l}0.26252^{* * * *} \\
(0.034)\end{array}$ \\
\hline Observations & 3,268 & 3,038 & 2,609 & 3,023 & 3,037 & 3,006 \\
\hline Number of banks & 515 & 496 & 478 & 500 & 497 & 494 \\
\hline$p$-Value for $\mathrm{AR}(2)$ test & 0.086 & 0.509 & 0.837 & 0.587 & 0.386 & 0.669 \\
\hline$p$-Value for Hansen $\mathrm{J}$-test & 0.516 & 0.835 & 0.619 & 0.795 & 0.842 & 0.867 \\
\hline Endogenous variables & LERNER & LERNER & LERNER & LERNER & LERNER & LERNER \\
\hline & $\operatorname{LERNER(-1)}$ & $\operatorname{LERNER(-1)}$ & $\operatorname{LERNER(-1)}$ & $\operatorname{LERNER}(-1)$ & $\operatorname{LERNER}(-1)$ & $\operatorname{LERNER}(-1)$ \\
\hline & $C A R$ & CAR & CAR & $C A R$ & $C A R$ & CAR \\
\hline & $G D P G$ & $G D P G$ & $G D P G$ & $G D P G$ & $G D P G$ & $G D P G$ \\
\hline
\end{tabular}


Table 4. Empirical results from the System GMM estimation without China and South Korea. (***), (**), and (*) indicate significance at the $1 \%$, $5 \%$ and $10 \%$ levels, respectively. Standard errors are in parentheses.

\begin{tabular}{|c|c|c|c|c|c|c|}
\hline \multirow[b]{2}{*}{ Explanatory Variables } & \multicolumn{2}{|c|}{ Loan growth } & \multicolumn{2}{|c|}{ Risk } & \multicolumn{2}{|c|}{ Market discipline } \\
\hline & $D L O A N$ & $L O A N G$ & $L L P$ & $S D R O A 3$ & $D D E P O$ & $D E P O G$ \\
\hline$D E P . V A R(-1)$ & $\begin{array}{l}-0.08285 * * * \\
(0.032)\end{array}$ & $\begin{array}{l}0.15942 * * * \\
(0.043)\end{array}$ & $\begin{array}{l}0.13731 * * * \\
(0.043)\end{array}$ & $\begin{array}{l}0.65119 * * * \\
(0.035)\end{array}$ & $\begin{array}{l}0.02918 \\
(0.038)\end{array}$ & $\begin{array}{l}0.06672 * \\
(0.038)\end{array}$ \\
\hline LERNER & $\begin{array}{l}-0.04816^{*} \\
(0.025)\end{array}$ & $\begin{array}{l}-0.14229 * * * \\
(0.042)\end{array}$ & $\begin{array}{l}0.03048 * * * \\
(0.010)\end{array}$ & $\begin{array}{l}0.00187 * \\
(0.001)\end{array}$ & $\begin{array}{l}-0.09541 * * * \\
(0.028)\end{array}$ & $\begin{array}{l}-0.12612 * * \\
(0.052)\end{array}$ \\
\hline $\operatorname{LERNER(-1)}$ & $\begin{array}{l}0.03080 \\
(0.023)\end{array}$ & $\begin{array}{l}0.08994 \\
(0.041)\end{array}$ & $\begin{array}{l}-0.01852 * * \\
(0.008)\end{array}$ & $\begin{array}{l}0.00083 \\
(0.001)\end{array}$ & $\begin{array}{l}0.05733 * * \\
(0.028)\end{array}$ & $\begin{array}{l}0.09952 * \\
(0.051)\end{array}$ \\
\hline$C A R$ & $\begin{array}{l}-0.00719 * * \\
(0.003)\end{array}$ & $\begin{array}{l}0.00080 \\
(0.004)\end{array}$ & $\begin{array}{l}-0.00219 * * * \\
(0.001)\end{array}$ & $\begin{array}{l}-0.00082 * * * \\
(0.000)\end{array}$ & $\begin{array}{l}-0.00222 \\
(0.003)\end{array}$ & $\begin{array}{l}-0.00878 \\
(0.005)\end{array}$ \\
\hline$D E P O$ & $\begin{array}{l}-0.01568 \\
(0.038)\end{array}$ & $\begin{array}{l}0.09704 * \\
(0.051)\end{array}$ & $\begin{array}{l}0.01062 \\
(0.008)\end{array}$ & $\begin{array}{l}0.00060 \\
(0.001)\end{array}$ & $\begin{array}{l}0.22738 * * * \\
(0.029)\end{array}$ & $\begin{array}{l}0.13609 * * \\
(0.067)\end{array}$ \\
\hline$N N I$ & $\begin{array}{l}-0.15036 * * \\
(0.070)\end{array}$ & $\begin{array}{l}-0.05099 \\
(0.131)\end{array}$ & $\begin{array}{l}0.03342 \\
(0.030)\end{array}$ & $\begin{array}{l}-0.00992 * * * \\
(0.003)\end{array}$ & $\begin{array}{l}0.04598 \\
(0.071)\end{array}$ & $\begin{array}{l}0.01317 \\
(0.153)\end{array}$ \\
\hline$S I Z E$ & $\begin{array}{l}-0.03560 \\
(0.050)\end{array}$ & $\begin{array}{l}-0.03168 \\
(0.065)\end{array}$ & $\begin{array}{l}0.04167 * * * \\
(0.008)\end{array}$ & $\begin{array}{l}0.00788 * * * \\
(0.002)\end{array}$ & $\begin{array}{l}0.04255 \\
(0.043)\end{array}$ & $\begin{array}{l}0.10157 \\
(0.103)\end{array}$ \\
\hline ECOFREE & $\begin{array}{l}0.05067 \\
(0.085)\end{array}$ & $\begin{array}{l}0.25835 * * \\
(0.124)\end{array}$ & $\begin{array}{l}-0.02872 \\
(0.018)\end{array}$ & $\begin{array}{l}-0.01078 * * * \\
(0.004)\end{array}$ & $\begin{array}{l}0.18149 * \\
(0.095)\end{array}$ & $\begin{array}{l}0.25453^{*} \\
(0.148)\end{array}$ \\
\hline$I N F$ & $\begin{array}{l}0.37468 * * \\
(0.159)\end{array}$ & $\begin{array}{l}0.41510^{*} \\
(0.223)\end{array}$ & $\begin{array}{l}-0.07166 * * * \\
(0.027)\end{array}$ & $\begin{array}{l}-0.00723 \\
(0.005)\end{array}$ & $\begin{array}{l}0.46389 * * * \\
(0.173)\end{array}$ & $\begin{array}{l}0.46914 \\
(0.303)\end{array}$ \\
\hline$G D P G$ & $\begin{array}{l}-0.00126 * * * \\
(0.000)\end{array}$ & $\begin{array}{l}-0.00213 * * * \\
(0.001)\end{array}$ & $\begin{array}{l}-0.00014 * \\
(0.000)\end{array}$ & $\begin{array}{l}0.00003 * * \\
(0.000)\end{array}$ & $\begin{array}{l}-0.00092 * * \\
(0.000)\end{array}$ & $\begin{array}{l}-0.00143 * \\
(0.001)\end{array}$ \\
\hline FOREXG & $\begin{array}{l}0.08031 * * * \\
(0.023)\end{array}$ & $\begin{array}{l}0.12078 * * * \\
(0.032)\end{array}$ & $\begin{array}{l}0.00563 \\
(0.004)\end{array}$ & $\begin{array}{l}-0.00077 \\
(0.001)\end{array}$ & $\begin{array}{l}0.15783 * * * \\
(0.021)\end{array}$ & $\begin{array}{l}0.21193 * * * \\
(0.045)\end{array}$ \\
\hline Observations & 2,757 & 2,568 & 2168 & 2,547 & 2,066 & 2,540 \\
\hline Number of banks & 409 & 397 & 381 & 401 & 315 & 397 \\
\hline$p$-Value for $\mathrm{AR}(2)$ test & 0.107 & 0.559 & 0.816 & 0.613 & 0.460 & 0.739 \\
\hline$p$-Value for Hansen $\mathrm{J}$-test & 0.990 & 0.999 & 1.000 & 0.992 & 0.998 & 0.997 \\
\hline Endogenous variables & $\begin{array}{l}\text { LERNER } \\
\text { LERNER(-1) } \\
C A R \\
G D P G\end{array}$ & $\begin{array}{l}\text { LERNER } \\
\text { LERNER(-1) } \\
C A R \\
G D P G\end{array}$ & $\begin{array}{l}\text { LERNER } \\
\text { LERNER(-1) } \\
C A R \\
G D P G\end{array}$ & $\begin{array}{l}\text { LERNER } \\
\text { LERNER(-1) } \\
\text { CAR } \\
\text { GDPG }\end{array}$ & $\begin{array}{l}\text { LERNER } \\
\text { LERNER(-1) } \\
\text { CAR } \\
\text { GDPG }\end{array}$ & $\begin{array}{l}\text { LERNER } \\
\text { LERNER(-1) } \\
\text { CAR } \\
\text { GDPG }\end{array}$ \\
\hline
\end{tabular}


Table 5. Empirical results from the weighted least squares regressions for all countries. $(* * *),(* *)$, and $(*)$ indicate significance at the $1 \%$, 5\% and $10 \%$ levels, respectively. Standard errors are in parentheses.

\begin{tabular}{|c|c|c|c|c|c|c|}
\hline \multirow[b]{2}{*}{ Explanatory Variables } & \multicolumn{2}{|c|}{ Loan growth } & \multicolumn{2}{|c|}{ Risk } & \multicolumn{2}{|c|}{ Market discipline } \\
\hline & DLOAN & $L O A N G$ & $L L P$ & SDROA3 & $D D E P O$ & DEPOG \\
\hline LERNER & $\begin{array}{l}-0.01475 \\
(0.013)\end{array}$ & $\begin{array}{l}-0.02753 * * * \\
(0.008)\end{array}$ & $\begin{array}{l}0.00970 * * \\
(0.004)\end{array}$ & $0.00080 *$ & $-0.01374 * *$ & $\begin{array}{l}-0.00370 \\
(0010)\end{array}$ \\
\hline$C A R$ & $\begin{array}{l}-0.46820 * * * \\
(0.067)\end{array}$ & $\begin{array}{l}0.07025 \\
(0.061)\end{array}$ & $\begin{array}{l}-0.17675^{*} \\
(0.097)\end{array}$ & $\begin{array}{l}-0.00027 \\
(0.002)\end{array}$ & $\begin{array}{l}0.07855^{* *} \\
(0.037)\end{array}$ & $\begin{array}{l}0.27500 * * * \\
(0.076)\end{array}$ \\
\hline$D E P O$ & $\begin{array}{l}-0.08252 * * \\
(0.039)\end{array}$ & $\begin{array}{l}-0.02913 \\
(0.027)\end{array}$ & $\begin{array}{l}-0.00651 \\
(0.012)\end{array}$ & $\begin{array}{l}-0.00087 \\
(0.001)\end{array}$ & $\begin{array}{l}0.19135^{* * * *} \\
(0.008)\end{array}$ & $\begin{array}{l}0.02997 \\
(0.042)\end{array}$ \\
\hline$N N I$ & $\begin{array}{l}0.10489 * * * \\
(0.037)\end{array}$ & $\begin{array}{l}-0.05482 * * \\
(0.027)\end{array}$ & $\begin{array}{l}0.00326 \\
(0.006)\end{array}$ & $\begin{array}{l}0.00451 * * * \\
(0.001)\end{array}$ & $\begin{array}{l}0.02787 \\
(0.020)\end{array}$ & $\begin{array}{l}0.01979 \\
(0.042)\end{array}$ \\
\hline$S I Z E$ & $\begin{array}{l}0.00490 * * \\
(0.002)\end{array}$ & $\begin{array}{l}-0.00520 * * * \\
(0.001)\end{array}$ & $\begin{array}{l}-0.00229 \\
(0.001)\end{array}$ & $\begin{array}{l}-0.00070 * * * \\
(0.000)\end{array}$ & $\begin{array}{l}-0.00471 * * * \\
(0.001)\end{array}$ & $\begin{array}{l}-0.00765 * * * \\
(0.002)\end{array}$ \\
\hline ECOFREE & $\begin{array}{l}-0.15370 * * * \\
(0.047)\end{array}$ & $\begin{array}{l}-0.31422 * * * \\
(0.032)\end{array}$ & $\begin{array}{l}0.02923 \\
(0.021)\end{array}$ & $\begin{array}{l}0.00539 * * * \\
(0.002)\end{array}$ & $\begin{array}{l}-0.15550 * * * \\
(0.021)\end{array}$ & $\begin{array}{l}-0.29145^{* * *} \\
(0.036)\end{array}$ \\
\hline INF & $\begin{array}{l}-0.35577 * * * \\
(0.066)\end{array}$ & $\begin{array}{l}0.31543 * * * \\
(0.046)\end{array}$ & $\begin{array}{l}0.01321 \\
(0.027)\end{array}$ & $\begin{array}{l}-0.00156 \\
(0.002)\end{array}$ & $\begin{array}{l}0.10053 * * * \\
(0.032)\end{array}$ & $\begin{array}{l}0.11697 \\
(0.083)\end{array}$ \\
\hline$G D P G$ & $\begin{array}{l}2.66888 * * * \\
(0.214)\end{array}$ & $\begin{array}{l}0.84186^{* * * *} \\
(0.141)\end{array}$ & $\begin{array}{l}-0.23118 * * * \\
(0.084)\end{array}$ & $\begin{array}{l}-0.01325 * * * \\
(0.005)\end{array}$ & $\begin{array}{l}0.72820 * * * \\
(0.094)\end{array}$ & $\begin{array}{l}1.12586 * * * \\
(0.146)\end{array}$ \\
\hline FOREXG & $\begin{array}{l}-0.13318 * * * \\
(0.027)\end{array}$ & $\begin{array}{l}0.12221 * * * \\
(0.018)\end{array}$ & $\begin{array}{l}0.00784 * * \\
(0.004)\end{array}$ & $\begin{array}{l}-0.00179 * * \\
(0.001)\end{array}$ & $\begin{array}{l}0.16582 * * * \\
(0.012)\end{array}$ & $\begin{array}{l}0.28055^{* * * *} \\
(0.025)\end{array}$ \\
\hline Observations & 3,532 & 3,369 & 3,087 & 3,353 & 3,371 & 3,351 \\
\hline R-squared & 0.746 & 0.218 & 0.265 & 0.257 & 0.301 & 0.165 \\
\hline Time dummies & Yes & Yes & Yes & Yes & Yes & Yes \\
\hline
\end{tabular}


Table 6. Empirical results from the weighted least squares regressions without China and South Korea. $(* * *),(* *)$, and $(*)$ indicate significance at the $1 \%, 5 \%$ and $10 \%$ levels, respectively. Standard errors are in parentheses.

\begin{tabular}{|c|c|c|c|c|c|c|}
\hline \multirow[b]{2}{*}{ Explanatory variables } & \multicolumn{2}{|c|}{ Loan growth } & \multicolumn{2}{|c|}{ Risk } & \multicolumn{2}{|c|}{ Market discipline } \\
\hline & DLOAN & $L O A N G$ & $L L P$ & SDROA3 & $D D E P O$ & $D E P O G$ \\
\hline LERNER & $\begin{array}{l}-0.02218 * * \\
(0.010)\end{array}$ & $\begin{array}{l}-0.0258 * * * \\
(0.009)\end{array}$ & $\begin{array}{l}0.00335^{* * * *} \\
(0.001)\end{array}$ & $\begin{array}{l}0.00251 * * * \\
(0.000)\end{array}$ & $\begin{array}{l}-0.02390 * * * \\
(0.006)\end{array}$ & $\begin{array}{l}-0.01195 \\
(0.010)\end{array}$ \\
\hline$C A R$ & $\begin{array}{l}-0.13142 * * * \\
(0.049)\end{array}$ & $\begin{array}{l}0.2203 * * * \\
(0.064)\end{array}$ & $\begin{array}{l}-0.02467 * * * \\
(0.007)\end{array}$ & $\begin{array}{l}-0.00090 \\
(0.002)\end{array}$ & $\begin{array}{l}0.04992 \\
(0.037)\end{array}$ & $\begin{array}{l}0.23350 * * * \\
(0.076)\end{array}$ \\
\hline$D E P O$ & $\begin{array}{l}-0.08035^{* *} \\
(0.035)\end{array}$ & $\begin{array}{l}0.0428 \\
(0.036)\end{array}$ & $\begin{array}{l}-0.00170 \\
(0.003)\end{array}$ & $\begin{array}{l}-0.00381 * * * \\
(0.001)\end{array}$ & $\begin{array}{l}0.15947 * * * \\
(0.019)\end{array}$ & $\begin{array}{l}0.00671 \\
(0.053)\end{array}$ \\
\hline$N N I$ & $\begin{array}{l}-0.11902 * * * \\
(0.045)\end{array}$ & $\begin{array}{l}-0.0711 \\
(0.044)\end{array}$ & $\begin{array}{l}0.03611 * * * \\
(0.003)\end{array}$ & $\begin{array}{l}0.01192 * * * \\
(0.001)\end{array}$ & $\begin{array}{l}0.01814 \\
(0.028)\end{array}$ & $\begin{array}{l}0.02556 \\
(0.059)\end{array}$ \\
\hline$S I Z E$ & $\begin{array}{l}-0.00611 * * \\
(0.003)\end{array}$ & $\begin{array}{l}-0.0040 \\
(0.003)\end{array}$ & $\begin{array}{l}-0.00070 * * * \\
(0.000)\end{array}$ & $\begin{array}{l}-0.00084 * * * \\
(0.000)\end{array}$ & $\begin{array}{l}-0.00549 * * * \\
(0.002)\end{array}$ & $\begin{array}{l}-0.01252 * * * \\
(0.003)\end{array}$ \\
\hline ECOFREE & $\begin{array}{l}0.01809 \\
(0.036)\end{array}$ & $\begin{array}{l}-0.2989 * * * \\
(0.035)\end{array}$ & $\begin{array}{l}-0.01466 * * * \\
(0.003)\end{array}$ & $\begin{array}{l}-0.00077 \\
(0.001)\end{array}$ & $\begin{array}{l}-0.11397 * * * \\
(0.022)\end{array}$ & $\begin{array}{l}-0.18798 * * * \\
(0.038)\end{array}$ \\
\hline$I N F$ & $\begin{array}{l}0.14648 \\
(0.111)\end{array}$ & $\begin{array}{l}0.0505 \\
(0.097)\end{array}$ & $\begin{array}{l}0.04450 * * * \\
(0.009)\end{array}$ & $\begin{array}{l}-0.00562 * \\
(0.003)\end{array}$ & $\begin{array}{l}0.05508 \\
(0.060)\end{array}$ & $\begin{array}{l}0.04395 \\
(0.113)\end{array}$ \\
\hline$G D P G$ & $\begin{array}{l}-0.94613 * * * \\
(0.170)\end{array}$ & $\begin{array}{l}0.5625 * * * \\
(0.160)\end{array}$ & $\begin{array}{l}-0.05090 * * * \\
(0.012)\end{array}$ & $\begin{array}{l}-0.00285 \\
(0.006)\end{array}$ & $\begin{array}{l}0.43503 * * * \\
(0.107)\end{array}$ & $\begin{array}{l}0.51071 * * * \\
(0.158)\end{array}$ \\
\hline FOREXG & $\begin{array}{l}0.01387 \\
(0.024)\end{array}$ & $\begin{array}{l}0.0897 * * * \\
(0.022)\end{array}$ & $\begin{array}{l}-0.00147 \\
(0.002)\end{array}$ & $\begin{array}{l}-0.00149 * \\
(0.001)\end{array}$ & $\begin{array}{l}0.12517 * * * \\
(0.015)\end{array}$ & $\begin{array}{l}0.20630 * * * \\
(0.029)\end{array}$ \\
\hline $\begin{array}{l}\text { Observations } \\
\text { R-squared } \\
\text { Time dummies }\end{array}$ & $\begin{array}{l}2,975 \\
0.103 \\
\text { Yes }\end{array}$ & $\begin{array}{l}2,835 \\
0.173 \\
\text { Yes }\end{array}$ & $\begin{array}{l}2,580 \\
0.511 \\
\text { Yes }\end{array}$ & $\begin{array}{l}2,816 \\
0.130 \\
\text { Yes }\end{array}$ & $\begin{array}{l}2,837 \\
0.206 \\
\text { Yes }\end{array}$ & $\begin{array}{l}2,819 \\
0.156 \\
\text { Yes }\end{array}$ \\
\hline
\end{tabular}

